\title{
Duyulara Hitap Etme Noktasında Ses - Ürün Etkileşimi: Çocuklarla, Oyuncaklar Ve Sesleri Üzerine Bir Çalışma
}

Arş. Gör. Cemil Yavuz

Makale Geliş Tarihi: 04.04.2017

Doç. Dr. Dilek Akbulut

Yayına Kabul Tarihi: 08.05.20I7

Prof. Dr. Aydın Şık

\section{Özet}

Görsel ve işitsel uyaranların kullanıcıların duyularına hitap etmesi, ürün üzerindeki etkiyi arttıran bir faktördür. Ürün kullanıcı etkileşimi dokunsal, görsel, işitsel, koku ve tat almayı kapsayan çok duyulu bir eksende gerçekleşmektedir. Kullanııılar ürünlerin duyusal niteliklerini bir bütün olarak algılama eğiliminde olmakla birlikte, aslında her bir duyunun ürünle olan etkileşimi ve deneyimdeki rolü sorgulanmalıdır. Bu duyulardan biri olan ses, kullanıcı deneyimini şekillendiren önemli bir unsurdur. Aynı zamanda ürün karakterini belirleyen faktörlerden biri olup, kullanıcıya ürünü anlamlandırma noktasında etkili bir geribildirim sağlamaktadır. Bu çerçevede ilköğretim birinci sınıfta okuyan öğrencilerle yapılan çalışmada ilk olarak öğrencilere belirli oyuncaklara ait sesler dinletilerek, bu sesin onlar üzerindeki çağrışımlarını belirtmeleri istenmiştir. Ikinci aşamada ise ses olmadan sadece oyuncaklara bakarak görsel açıdan her birini yorumlamaları istenmiş, son aşamada ise sesler tekrar dinletilip sesin hangi ürüne ait olabileceği sorularak, ses-görsel ilişkilendirmesi yapılmıştır. Belirli seslerin, ürünlere ait ses deneyimini nasıl etkileyeceğini anlamak adına yapılan bu çalışmada, sesin görsel ile uyumu sorgulanmıştır.

Anahtar Kelimeler: Duyular, Ses, Ürün formu, Oyuncak, Ürün-Kullanıcı Etkileşimi

\section{SOUND-PRODUCT INTERACTION FOR APPEALING SENSES: A STUDY ON CHILDREN, TOYS AND SOUNDS}

\begin{abstract}
Appealing the senses of users by visual and auditory stimuli is a factor that increases the impact of a product. Users intend to perceive the sensory qualities of a product as a whole; however each sense's interaction with the product and the role on the experience should be questioned. Within the framework of the study, first year elementary school students were presented only the sounds of certain toys and the students were asked to indicate the connotation of the presented sounds in the first stage. In the second stage the students were presented only the image of the toys and were asked to interpret each toy visually. In the last stage, the students were asked to match the sound and image of the toys. The study aims to understand how certain sounds affect sound experience and to question sound's compliance with the image of a product.
\end{abstract}

Keywords: Senses, Sound, Product form, Toy, Product-User Interaction 


\section{Giriş}

Çevreyi algılama ve analiz etme sürecinde önemli bir kavram olarak ortaya çıkan algı, nesnel dünyayı duyular yolu ile öznel bilince aktarma biçiminde tanımlanmaktadır (Özcan, Bayraktar, Göker ve Tekel, 2003: 19). Algılama, bir organizmanın gereksinimlerini karşılamak için çevresel bilgileri bir yöntemle elde etmek süreci olarak düşünülebilir (Genç ve Sipahioğlu, 1990). Dökmen (1994) algıyı, "duyu organlarından beyne ulaşan verilerin örgütlenmesi, yorumlanması ve anlamlandırılması süreci" olarak ifade ederken, Aydınlı (1992) ise "çevreden gelen uyarıcıların duyu organları yoluyla kavranıp anlaşılması" olarak tanımlamaktadır. Algılama, duyu organlarını uyaran nesnelerin, farkında olunması gerektiğinden, ortam, duygusal deneyim, tutum, amaç ve dürtüler tarafından etkilenmektedir. İnsan ve nesne etkileşimi, algılama, bilme ve düşünmeyi içermektedir. Insan çevresindeki nesnelerle sürekli etkileşim halinde olduğundan kendi intiyacına cevap verenlere öncelik tanır ve bu seçimin altında önceden edindiği bilgiler yatmaktadır. Çünkü seçim sırasında nesneyle geçmişte edindiği bilgiyi birlikte değerlendirir. Bu şekilde özne- nesne etkileşiminin devamlılığ sağlanmaktadır. Nesnel dünya, duyular sayesinde öznel bilince aktarılmaktadır (Çağlayan, Korkmaz ve Öktem, 2014: 168). Duyu organlarımızın ilettiği ham ve işlenmemiş duyuların yorumlanması ve anlamlanması sonucu ortaya çıkan algılar, beş duyumuza göre sınıflandırılmaktadır. Bu çalışmada genel etkileşim olgusu içerisinde görsel ve işitsel bildirilerin ürünlerdeki etkinliği üzerinden gidileceği için görsel ve işitsel algının üzerinde durulacaktır. Gestalt kuramcıları görsel öğenin önemini özetle şu şekilde belirtmektedir; "insanoğlu dış dünyaya ilişkin bilgilerinin \% 85'ini görme duyusu aracılığıyla edinir. Bu yüzden insan ile çevre arasındaki ilişkilerin genel sorunu içinde görsel bildirim ve estetik algılama odak noktası niteliğindedir" (Erhan, 1978). Görsel algı, uyarıcının sahip olduğu anlam, kişinin uyarıcıyı önceden tanıması, kültür farklılıkları, zihinsel farklılıklar vb. etmenlere göre şekil alacağından, kişiden kişiye değişen bir olgudur. Mekânı veya nesneyi algılamakta en etkili faktör görsel algılama olsa da, işitsel algılama da bu duruma destek olmaktadır. Algılamada mevcut duyuların sayısı arttıkça, algılama daha doğru ve net bir hale gelir. Bu bakımdan sesler, mekânı veya nesneyi algılamamız konusunda görme duyumuza yardım etmektedir. Örnek olarak bir mekândaki müzik sesi ya da insan sesi gibi bir etken, o mekânı algılama biçimimizi değiştirebilmektedir (Çağlayan, Korkmaz ve Öktem, 2014: 169).

Nesnelerin algılanmasında fiziksel ve fizyolojik sınırlarımızı etkileyen koşullardan bir diğeri de estetik değerdir. Estetik değerin algıya katkısını bir örnekle açıklamak gerekirse; tamamen düzenli karelerden oluşan bir 
düzlemde bir tek karenin diyagonal durması, farklı renkte olması veya yer değiştirmesiyle içerik etkenlere bağlı olarak artacaktır. Çünkü bu etkenler yenidir, uyarıcıdır ve gerilim yaratmaktadır (Erhan, 1978). Dolayısıyla estetik deneyim, insanın bir konuya dikkatini toplaması, geçmiş ve gelecek konusundan haberdar olması, çevresel problemleri çözümleme becerisi, dıştan ödül beklemeden kendi kendine tatmin olması şeklinde tanımlanabilir (Csikszentmihalyi ve Robinson, 1990). Bir sanat eserinden gelen enformasyon, seyredenin aklındakilerle etkileşime geçerek estetik deneyim oluşur. Tasarımdan edindikleri deneyimler aynı olmadığı için, deneyimsiz bir yeni tasarım öğrencisiyle yetişkin bir tasarımcının gördükleri farklı olacaktır. Estetik algısı zaman ve mekâna göre de farklıık göstermektedir. Eskiden güzel bulunan bir eser, günümüzde çekiciliğini kaybetmiş olabilir. Estetik değerin nasıl oluştuğuna dair pek çok görüş bulunmaktadır. Bunlardan biri olarak Bayazıt (2011: 137) estetik değerin, insanın özellikleriyle olan ilişkisinde var olduğunu, bu değeri belirleyenin ise alıcı değil o nesnenin tasarımcısı ve hatta tasarımcının içinde bulunduğu zaman ve kültür olduğunu belirtmiştir.

\section{Ürün-Kullanıcı Etkileşiminde Görsel ve Duysal Uyarılar}

Zaman göstergesi olan saat, zamanı görsel iletişim yoluyla bildirecek biçimde tasarlanmıştır. Bazı saat tasarımlarında ise bu durum, duysal iletişimle de birleştirilmiştir. Belirli zamanlarda ses sinyalleriyle zamanı bildiren saatler olsa da bu sinyali duysal olarak algıladıktan sonra görsel olarak saatin kaç olduğunu denetleme yoluna gidilmektedir. Bunun yanında görsel etkileşim olmadan, belirli zamanlarda yapılması gereken davranış ve eylemlerin başlangıç ve bitiş zamanlarının sadece sesli olarak bildirilmesi de (teneffüs saati, paydos saati vb.) olasıdır. Duysal iletişim bazen de güvenlik amacıyla görsel iletişimle birlikte kullanılmaktadır. Örneğin, masaüstü bir hoparlörün açık olan düğmesini kapalı konuma getirdiğimizde ortaya çıkan "çıt" sesi, yani duysal uyarı, görsel iletişimi güçlendiren bir emniyet işareti olarak değerlendirilebilir. Görme ve duymanın bilgi iletimine ilişkin uygunluklarını karşılaştıran Henneman bazı özelliklere değinmiştir. Bunlardan bazılarını sıralamak gerekirse; duysal uyarılar gerçekte zamansal iken, görsel uyarıların uzay içinde belirli konumları vardır. Duysal bildirilerin iletim oranı ses çıkarma oranıyla sınırlıyken, görsel bildiriler doğrudan bellekle ilişki kurarak daha hızlı olabilir. Duysal iletişim daha çok dikkat gerektirirken, görsel iletişimde kullanııının nesneyi algılamak için dinlemeye bağlı olmayıp göstergeye bakması yeterlidir (McCormick, 1970).

Çevremizdeki birçok nesne ses çıkarmaktadır. Bir otomobil motorunun sesi, alarm sesi, geribildirim sesleri, vs. Tüm bu sesler kişilerin algııını etkilemek 
üzere bilinçli veya bilinçsiz bir şekilde çıkartılmaktadır. Van Egmond (2008: 72) ses tasarımı noktasında bir ayrıma giderek bu sesleri ikiye ayırmıştır. Bunlardan ilki ürünlerin fonksiyonu sonucu kullanılan malzemeye, boyuta, ürün geometrisine, enerji kaynağına bağlı olarak değişebilecek olan dolaylı seslerdir. Diğeri ise ses tasarımcıları tarafından üzerine çalışılarak tasarlanan istemli seslerdir. Saç kurutma makinesi, elektrikli süpürge gibi ürünlerden çıkan sesler dolaylı seslere örnek olarak verilebilirken; mikrodalga fırındaki zil sesi, alarm saati sesi, vs. ise istemli seslere örnek gösterilebilir (Özcan ve Van Egmond, 2012: 43).

Ürün deneyimini, ürün kullanıcı etkileşimine bağı temel etkilerdeki değişiklik olarak tanımlamak mümkünken, Hekkert (2006: 160) ürün deneyimini estetik zevk, anlamın özelliği ve duygusal tepki olarak üç bileşenden oluştuğunu belirtmektedir. Estetik zevki oluşturan daha önce de bahsettiğimiz estetik deneyim olup, ürünlere bizim atadığımız anlamlar anlamın özelliğini, etkileşim sonucu ortaya çıkan his ve duygular ise duygusal tepkiyi oluşturmaktadır. Günlük yaşamdaki objeler üzerinden örnek vermek gerekirse; koltuğun yumuşak ve tüylü dokusunun kişide mutluluk hissi uyandırması estetik deneyimlerimizdir. Bir kahve makinesini maskülen, bir cep telefonunu sade ve anlaşlır bulmak, anlamdaki deneyimlerimizdir. Karmaşık yapıya sahip bir arayüzün kişiyi sinirlendirmesi gibi deneyimler de duygusal deneyimlerimize örnek gösterilebilir (Desmet ve Hekkert, 2007: 61). Tüm bu deneyimler birbirinden bağımsız görünse de kullanıcı ürün etkileşiminde birbirlerini etkilemektedir. Desmet (2003: 5) bu etkileşimde açığa çıkan duyguyu Şekil 1'de görüldüğü gibi basit bir şemayla açıklamışır.

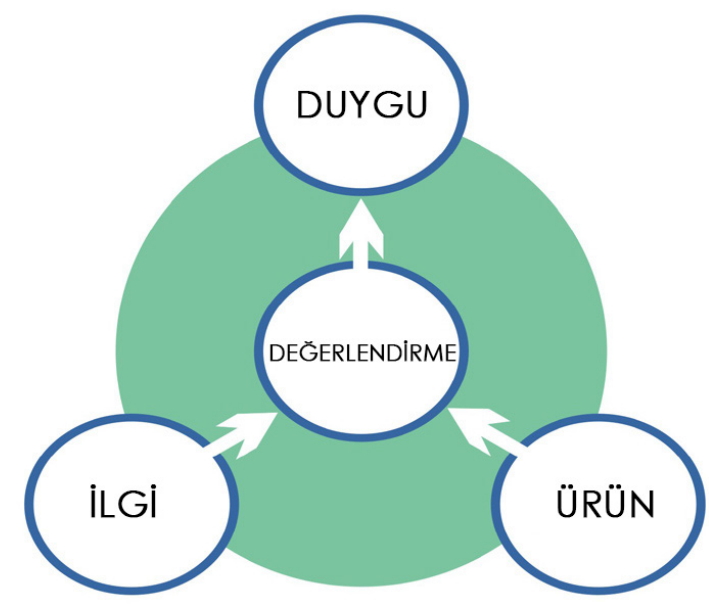

Şekil I. Ürün Duygularının Açığa Çıkısııı Gösteren Temel Model (Desmet, 2003: 5) 
Bir nesnenin bizde bir duygu oluşturması için öncelikle ilgi alanımıza girmesi gereklidir. İlgimizi çekmesi yani algılama alanımıza girebilmesi için de uyarı olgularını içermesi gerekir. Bu uyarılar, işaretler, sesler, bilgi taşıyıcılarıdır. Duyu organlarını harekete geçiren bu uyarılar nesnelerinin algılanmasının temelini oluşturmaktadır (Erhan, 1978). Nesneyi algılamamız için gerekli olan uyarılar ürünün formundan içeriğine kadar tüm bileşenlerini kapsamaktadır. Ürün formu bir anlamda ürünün kişiliğini yansıtan bir olgudur. Kişiliğin sözlük tanımı, bir kimseye özgü belirgin özellik, manevi ve ruhsal niteliklerinin bütünüdür (TDK, 2015). Kullanıcılar belirli ürünleri kullanarak kendilerini dışarıya karşı ifade ettiklerini düşünürler. Hekkert ve Leder (2008: 263), eğer bir ürün, bir kişinin kişiliğini tanımlamasına ve sürdürmesine katkıda bulunuyorsa, sahibi için özel bir anlamı olduğunu belirtmektedir. Ürün tasarımında da ürüne ait belirleyici, kendini ifade edeceği bir tasarım stratejisi uygulanması, diğerlerinden ayırt edilmesi noktasında ürüne kişilik kazandırılması anlamına gelmektedir. Bazı ürünlerde bu tür kişilik kazandırma çabaları insanları ürünü satın almaya çekmek için strateji olarak uygulanmaktadır.

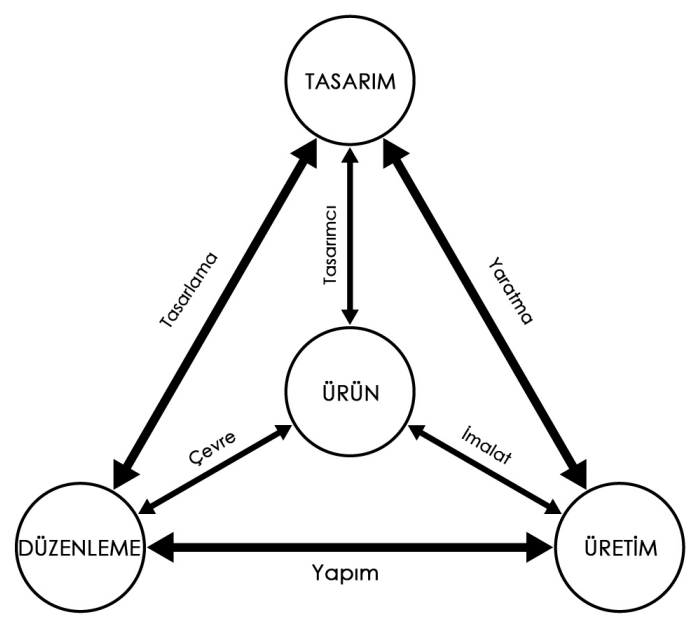

Şekil 2. Üretim Alanları, Düzenleme Ve Tasarımın Ürün Ile Ilişsisi (Langeveld, Van Egmond, Jansen Ve Özcan, 2013: 5I)

Ürünlerin formları, kullanılan malzemeler, renk etkileri, çıkardığı ses, sahip olduğu fonksiyonlar, kullanıcıların ürünleri fark etme noktasında önemli niteliklerdir. Tasarımcılar bu noktada verdikleri kararlarla ürünlerin tercih edilmesi, kullanıcılarda merak uyandırması, onlara gerek estetik gerek anlamsal deneyimler kazandırarak duygusal dünyalarını etkilemesi açısından kişilikli ürünler ortaya koymaları önemlidir. Ürünlere verilecek form, renk, kullanım detayları, malzeme ve ses kullanıcılarda hoşlanma, 
coşku, mutluluk gibi olumlu çıktılar verebileceği gibi tam aksi bir durum da ortaya çıkartabilir. Bu durumun olumlu olması sonucunda kullanıcılar kendi ürünlerini diğer ürünlerle karşılaştırarak, kendi ürünlerini anlamlı kılacaklardır. Şekil 2'deki grafikten anlaşılacağı üzere bir ürünün ortaya çıkmasında üç temel alan bulunmaktadır. Bunlardan tasarım yani bir ürünün şekillenmesi noktasında verilecek kararlarda tasarımcılar baskın olarak karar verici konumundadır. Burada düzenleme evresinden kasıt, ürünün teknik problemlerinin çözümünden ziyade yaratıcı problem çözümüdür. İmalat sürecinde tasarımcılar, malzemeye veya çeşitli limitlere bağlı olarak, şekil, hacim gibi boyutsal kararlar alma noktasında müdahalede bulunurlar.

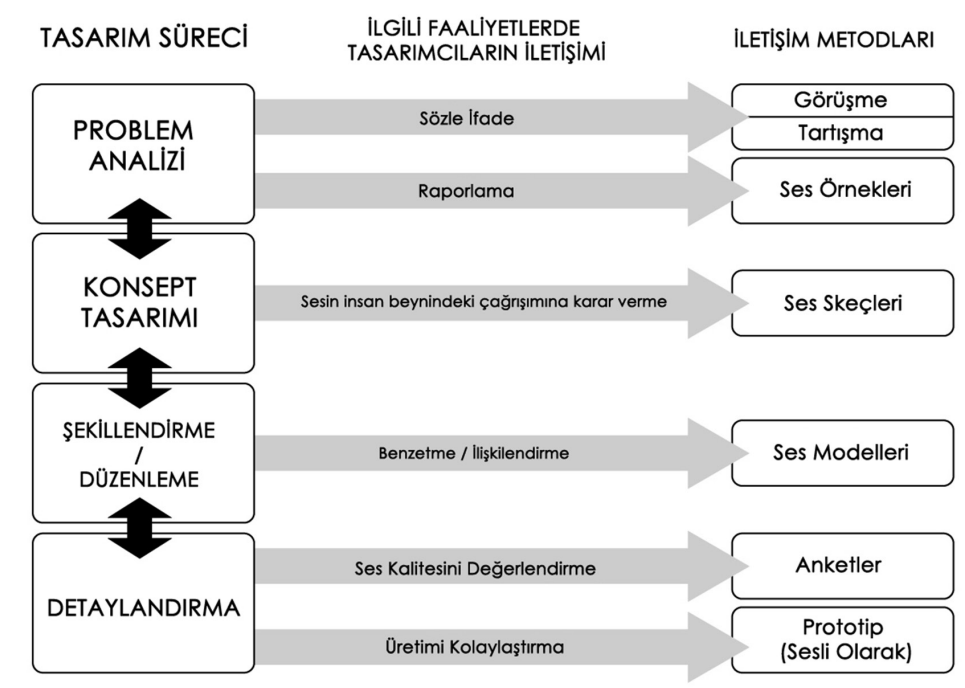

Şekil 3. Illgili Faaliyetlerde Ürün Sesi Tasarım Metotları (Özcan ve Van Egmond, 2008: 306)

Tüm bu seçimlerin yanında ürünün çıkaracağı sese karar vermek de yönetim ve ürün geliştirme ekibinin sorumluluğundadır. Üründeki dolaylı ve istemli seslerin ortaya çıkmasına firmanın mühendislik ve tasarım bölümleri karar verirken bu süreç dört aşamada gerçekleşmektedir. Bunlar; ürün kullanımı kapsamında ses analizi, ses skeçleriyle fikirlerin kavramsallaştırıması, prototiplerle konsepti şekillendirme ve amacına yönelik hassas ses ayarı yaparak detaylandırma aşamalarıdır (Özcan ve Van Egmond, 2008: 306) (Şekil 3).

Bir ürünün tasarımından kullanım evresine kadar olan süreçte birçok değişkene bağlı olarak kararlar alındığına göre, bu seçimlerin ürünün geleceğini belirlediğini söyleyebiliriz. Ürünü sadece form olarak ortaya çıkarmak yeterli olmayıp, onun kim tarafından kullanacağı, kullanıcı 
deneyimleri, kullanıcı algısı gibi faktörlere göre ürünün tüm çıktılarını doğru kurgulamak gerekmektedir. Oyuncak da bu ürün gruplarından bir tanesidir ve kullanıcı kitlesi her ne kadar çocuklar olsa da bu kümenin içine bazen büyükler de girmektedir. Oyuncaklar yapıldıkları döneme ilişkin çeşitli kültürel özellikleri yansıtmasının yanı sıra oyuncak kavramı ve oyuncak endüstrisi, içinde bulunulan dönemle ilişkili olarak gelişim göstermiştir (Çelebi, 2007). 1880'li yıllardan itibaren oyuncak endüstrisinde büyük gelişmeler yaşanmış, 'çocuk gelişimine uygun oyuncak' düşüncesi öne çıkmıştır. 1990'lı yıllardan itibaren 'eğitimsel oyuncak' önem kazanmış, çeşitli kavramları geliştirmede yardımcı materyaller olarak kullanılmaya başlanmıştır (Kim, 2002: 801). Oyuncakçlık, dünyada büyük oranda zanaat geleneğine dayalı olarak gelişmiştir. Soylu ve varlıklı ailelerin çocukları için yapılan oyuncaklar, zaman içinde sosyal değişim ve endüstriyel gelişimle seri üretilen, kolay erişilebilen bir hal almıştır. Eskinin ağır şartlarda çalışan çocuğu, oyuncağa zaman ve para ayıramazken, bugün her kesimden çocuk için oyuncak üretilmektedir (Akbulut, 2009: 182). Oyunlar için araç konumunda (Jackson, 2001: 141) ve çocuk oyunlarının ayrılmaz parçası olan oyuncaklar, çocukların sosyal ve bilişsel becerilerini uyarıcı oyunlar için zemin oluşturmanın (Blakemore ve Centers, 2005: 623) yanı sıra onların oyun yönelimleri ve oyun teması üzerinde de önemli bir etkiye sahiptir (Kim, 2002: 802). Oyuncaklar, çocukların farklı beceriler kazanmasında ve bunları geliştirmesinde, taşıdıkları özellikler temelinde farklı düzeylerde katkı sağlamakta ve etkili olabilmektedir. Çocukların ruh ve beden sağlığı açısından, oyun ve oyuncak önemli bir yer tutmaktadır.

Oyun ortamının hazırlanması kadar oyuncak seçimi de bu noktada önemlidir. Oyuncaklar, sadece çocukları oyalamakla kalmayıp, aynı zamanda onların zihin gelişimlerinin de destekçisidir. Oyuncaklar, çocukların problem çözmesini öğrenmede, kendi bedenlerini daha iyi tanımada, üreticiliklerini geliştirerek liderlik yeteneklerini kazanmada önemli bir yer tutmaktadır (AÖF, 2014). Oyuncak seçiminde güvenliğin yanı sıra oyuncağın gelişim düzeyine uygunluğu, çeşitli oyunlarda değişik şekillerde kullanılabilmesi özelliği de önemlidir. Yeni doğan bir bebeğin oyuncağı kendi bedenidir. Çıkarabildiği sesleri tekrarlayarak kendini oyalar ve annesinin veya yakınındaki bir yetişkinin yaptığı hareket, çıkardığı ses onda heyecan yaratır. Doğumu izleyen ilk aylarda çocuk, ses, şekil ve renge karşı hassastır (Yalçınkaya, 1993: 170). İlerleyen yaşlarda kabiliyetleri değişen çocuklarda her yaş grubunun kendine has özellikleri olduğu için ona uygun olan oyuncak da değişim gösterecek, dolayısıyla oyuncak tercihleri buna göre şekillenecektir. Çocuğun ilkokula başlamasıyla oyun ve oyuncak ihtiyacı sona ermeyip, okul döneminin bitimine kadar her türlü oyun malzemesinden yararlanmaktadır. 
Çocukların eğitimi üzerine çalışmalar yapan Montessori, çocuğun gelişimini (0-6), (6-12) ve (12-18) yaş arası dönemler olarak üç evreye ayırmış, öğrenmenin en yoğun olduğu dönemin (0-6) yaş aralığı olduğunu belirtmiştir (Schafer, 2006). Montessori 3-6 yaş arasındaki çocukluk dönemini mükemmellik evresi olarak nitelendirmektedir. Bu dönemden önce nesneleri emerek beyninde depolayan çocuk, artık duyu organlarılya dünyayı anlamlandırmaya çalışmaktadır. Montessori'ye göre (6-12) yaş evresindeki çocuk, toplumsal alanda yeni doğmuş bir bebektir. Birlikte yaşamanın gerektirdiği düzenlemeler, kurallar ve ahlak öne çıkmaktadır. Bu evrede çocuğun vicdanı, iyi ile kötü, doğru ile yanlış arasındaki davranışı ayırt etmenin karar merkezi haline gelir ve çocuk sosyal bilince ulaşmayı başarır (Wilbrandt, 2009). Duyular yardımıyla sürekli bir öğrenmenin içerisinde olan çocuk, her dönem bir önceki döneme bir şeyler ekleyerek bilişsel bir sistem geliştirmektedir.

Bu gelişimin tüm aşamaları kendi içerisinde ayrı bir öneme sahip olduğu için çocuk eğitiminde her dönem hassasiyetle takip edilmelidir. Çocukların fizyolojik ve psikolojik açıdan gelişimlerini etkileyen unsurlardan biri olan oyuncakların başta üreticilerine ve bu oyuncakların seçiminde etkili olan ebeveynlere büyük sorumluluklar düşmektedir. Bu araştırma, çocukların oyuncakları duyuları aracılığıla nasıl algıladıklarını belirlemek amacıyla yapılmıştır. Kendilerini daha rahat ifade edebilecekleri düşünülerek, henüz belirli kalıplara girmemiş, Montessori'ye göre toplumsal alanda yeni doğmuş bir bebek olarak adlandırılan dönem olan (6-12) yaş döneminin başında olan çocuklar katılımcı olarak belirlenmiştir. Araştırma sonuçları doğrultusunda çocukların duyuları ile oyuncak algılarının belirlenmesi, oyuncak üreticilerinin, ebeveynlerin ve eğitimcilerin bu konudaki duyarlılıklarının arttıııması ve yapılacak diğer çalışmalara bir basamak oluşturması amaçlanmıştır.

\section{Araştırmanın Modeli}

Araştırma betimsel bir durum saptaması niteliğinde olup, nitel araştırma teknikleri temel alınarak kurgulanmıştır. Araştırmada nitel araştırma çeşidi olan tipik durum çalışması yöntemi kullanıımıştır. Durum çalışmalarındaki amaç belirli bir duruma ilişkin sonuçlar ortaya koymaktır (Yıldırım ve Şimşek, 2008). Oyuncağın yapısal formu ve çıkardığı sesin çocuklar üzerindeki etkisi, çocukların oyuncaklara yükledikleri anlamları ve oyuncakların çıkardıkları seslerin oyuncağın formu ile örtüşüp örtüşmediğini anlamak adına yapılan bu araştırmada, durumu ortaya koyabilmek için ilköğretim birinci sınıftaki öğrencilerle görüşme yapılmıştır. 


\section{Katılımcılar}

Araştırmada amaçlı örnekleme yöntemlerinden ölçüt örnekleme yöntemi kullanılmıştır. Ölçüt örnekleme, bir dizi ölçütü karşılayan bütün durumların çalışılmasıdır (Yıldırım, Şimşek, 2008). Araştırmada, oyun çağında olan 6-9 yaş aralığındaki çocuklarla çalışılması ölçüt olarak belirlenmiştir. Araştırmanın katılımcıları; Ankara ili, Milli Eğitim Bakanlığına bağlı, bağımsız bir ilköğretim okulunda eğitim gören toplam 11 öğrenciden oluşmaktadır. Çocukların her biri 7 yaşındadır.

\section{Verilerin Toplanması}

Bu araştırmanın verileri Ocak 2015 tarihinde, öğrencilerin uygun oldukları zamanda, kendi okullarında yapılan görüşmeler yoluyla toplanmıştır. Verilerin toplanmasında, görüşme türlerinden yarı-yapılandırılmış görüşme tekniğinden yararlanılmıştır. Araştırmacı tarafından belirlenen 8 oyuncak üzerinden sorulan sorularla, öğrencilerin oyuncaklara ilişkin görüşleri belirlenmiştir. Görüşmeler üç aşamada gerçekleşmiştir. Birinci aşamada öğrenciye oyuncağın kendisi gösterilmeden, sadece her bir oyuncağa ait sesler sırayla dinletilerek, seslerin onda çağrıştırdı ğı anlamlar sorgulanmıştır. İkinci aşamada öğrenciye oyuncağın görseli gösterilerek, sesleri olmadan sadece form olarak oyuncağı yorumlaması istenmiş, üçüncü aşamada ise oyuncaklara ait sesler tekrardan sırayla dinletilerek, önlerindeki oyuncaklarla bu sesleri eşleştirmesi istenmiştir. Her bir öğrenci ile bire bir görüşme yapılmış ve görüşmeler yaklaşık 10 dakika sürmüştür.

\section{Verilerin Analizi}

Toplam 15 çocukla görüşme yapılması planlanmış olmasına rağmen soruları yanıtsız bırakan, soruları anlamayan çocuklar araştırma kapsamına alınmamıştır. Veriler 8 kız, 3 erkek, toplam 11 çocuktan alınan yanıtlar üzerinden değerlendirilmiştir. Öğrencilerin verdikleri cevaplardan elde edilen verilerin çözümlenmesinde betimsel analiz tekniği kullanılmıştır. Betimsel analiz tekniği ile veriler özetlenmiş ve yorumlanmıştır. 


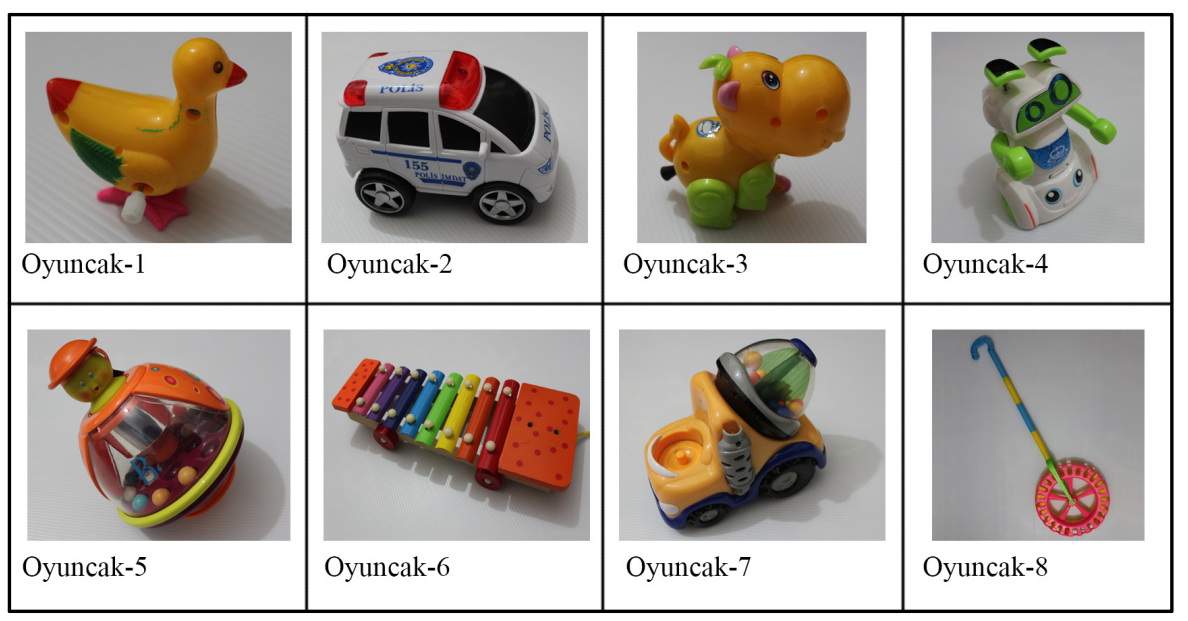

Tablo I. Çalışmada Kullanılan Oyuncaklar

\section{Bulgular}

Bu bölümde öğrenciler ile yapılan görüşmelerden elde edilen bulgular, sorulara göre sıralanarak verilmiştir. Görüşmede her bir çocuğa ilk olarak oyuncakların hiçbiri gösterilmeden sadece 8 oyuncağa (Tablo 1) ait sesler sırasıyla dinletilmiş ve bu seslerin onlar üzerindeki etkilerini belirtmeleri istenmiştir. Bu aşamada öğrencilere üç soru sorulmuştur. İlk soruda sırayla dinledikleri seslerin hoş ve güzel bir ses mi olduğu yoksa rahatsız edici mi olduğu sorulmuş, verilen yanıtlar Tablo 2'de aktarılmıştır. " "- işareti rahatsız edici, "+" işareti de hoş ve güzel anlamına gelecek şekilde tabloda kullanılmıştır. Genel olarak tüm sesler rahatsız edici bulunmasa $\mathrm{da}, 6$. oyuncak olan müzik aletini anımsatan oyuncak dışında en az bir kişi seslerin herhangi birinden rahatsız olduğunu belirtmiştir. Bu oyuncağın belirli notaları çıkartan, tanımlı bir sese sahip olması sonucu çocukların bu sesi tanıdık bulması nedeniyle onlarda herhangi bir rahatsızlığa yol açmadığı söylenebilir.

\begin{tabular}{|l|l|l|l|l|l|l|l|l|l|}
\hline Çocuk & $\begin{array}{l}\text { Kuz/ } \\
\text { Erkek }\end{array}$ & $\begin{array}{c}\text { Oyuncak } \\
1\end{array}$ & $\begin{array}{c}\text { Oyuncak } \\
2\end{array}$ & $\begin{array}{c}\text { Oyuncak } \\
3\end{array}$ & $\begin{array}{c}\text { Oyuncak } \\
4\end{array}$ & $\begin{array}{c}\text { Oyuncak } \\
5\end{array}$ & $\begin{array}{c}\text { Oyuncak } \\
6\end{array}$ & $\begin{array}{c}\text { Oyuncak } \\
7\end{array}$ & $\begin{array}{c}\text { Oyuncak } \\
8\end{array}$ \\
\hline Ç 1 & K & + & + & + & + & + & + & + & + \\
\hline Ç 2 & E & + & + & + & + & - & + & + & + \\
\hline
\end{tabular}

Tablo 2. Dinletilen Oyuncak Seslerinin Rahatsız Edici mi (-) Yoksa Hoş ve Güzel (+) Bir Sese mi Sahip Olduğu Sorusuna Verilen Cevaplar 


\begin{tabular}{|l|l|l|l|l|l|l|l|l|l|}
\hline Ç 3 & $\mathrm{K}$ & - & - & - & - & - & + & + & + \\
\hline Ç 4 & $\mathrm{E}$ & + & + & + & + & + & + & + & + \\
\hline Ç 5 & $\mathrm{~K}$ & + & + & + & + & + & + & + & + \\
\hline Ç 6 & $\mathrm{~K}$ & - & - & + & - & - & + & - & - \\
\hline Ç 7 & $\mathrm{E}$ & + & + & + & + & + & + & + & + \\
\hline Ç 8 & $\mathrm{~K}$ & + & + & + & + & + & + & + & + \\
\hline С̧ 9 & $\mathrm{~K}$ & + & + & + & + & + & + & + & + \\
\hline С 10 & $\mathrm{~K}$ & + & + & + & + & + & + & + & + \\
\hline С 11 & $\mathrm{~K}$ & - & - & - & - & + & + & - & - \\
\hline
\end{tabular}

Tablo 2 (Devamı). Dinletilen Oyuncak Seslerinin Rahatsız Edici mi (-) Yoksa Hoş ve Güzel (+) Bir Sese mi Sahip Olduğu Sorusuna Verilen Cevaplar

İkinci soruda ise dinledikleri sesleri neye benzettikleri sorulmuş, verdikleri cevaplar Tablo 3'de aktarılmıştır. Birinci oyuncak kurmalı bir oyuncak olup, bir ördek formunda tasarlanmıştır. Fakat tablodan da görüleceği üzere öğrenciler bu sesi, tren, araba veya yılan seslerine benzetmişlerdir. İkinci oyuncak polis arabası formunda bir oyuncak olup, çıkardığı mekanik sese öğrencilerin geneli araba veya motor diyerek sonucu doğru tahmin etmişlerdir. Dördüncü oyuncak bir robot olup birden fazla sesi arka arkaya çıkarmaktadır. Bu sese yapılan yorumlarda sadece iki kişi bunun robot olabileceğini belirtmiş̧ir. Altıncı oyuncak az önce belirtildiği gibi bir müzik aleti olduğu için, öğrencilerin büyük çoğunluğu bunun müzikle ilgili olduğunu ifade eden sıfatlar kullanmışlardır. Sekizinci oyuncak da birden fazla sese sahip olup, belirgin bir yere ait olmadığı için sesle ilgili yapılan yorumlarda çeşitlilik gözlenmiştir. Bu oyuncak, tekerleğin dönmesiyle ve içindeki zilin çalmasıyla iki farklı ses açığa çıkarmaktadır. Bu ürüne yapılan yorumlarda zil sesi baskın olduğu için tekerlek sesinin algılanmaması sonucu ağırlıklı olarak zile, miskete veya taşlara benzetilmiştir.

\begin{tabular}{|l|l|c|c|c|c|c|c|c|c|}
\hline Çocuk & $\begin{array}{l}\text { Kız/ } \\
\text { Erkek }\end{array}$ & $\begin{array}{c}\text { Oyuncak } \\
1\end{array}$ & $\begin{array}{c}\text { Oyuncak } \\
2\end{array}$ & $\begin{array}{c}\text { Oyuncak } \\
3\end{array}$ & $\begin{array}{c}\text { Oyuncak } \\
4\end{array}$ & $\begin{array}{c}\text { Oyuncak } \\
5\end{array}$ & $\begin{array}{c}\text { Oyuncak } \\
6\end{array}$ & $\begin{array}{c}\text { Oyuncak } \\
7\end{array}$ & $\begin{array}{c}\text { Oyuncak } \\
8\end{array}$ \\
\hline Ç 1 & K & Tren & Araba & $\begin{array}{c}\text { Küçük } \\
\text { Araba }\end{array}$ & Araba & Kepçe & $\begin{array}{l}\text { Bilgisayarda } \\
\text { müzik }\end{array}$ & Tren & Araba \\
\hline Ç 2 & E & Tren & Araba & Kamyon & Araba ateş & Patlayıc1 & Müzik sesi & Tren & Değnek \\
\hline
\end{tabular}

Tablo 3. Dinletilen Seslerin Neye Benzediğine Dair Verilen Cevaplar 


\begin{tabular}{|c|c|c|c|c|c|c|c|c|c|}
\hline Ç 3 & K & $\begin{array}{r}\text { Müzik } \\
\text { Aleti }\end{array}$ & Testere & $\begin{array}{c}\text { İlerleyen } \\
\text { birşey }\end{array}$ & $\begin{array}{l}\text { Ateș, } \\
\text { Silah }\end{array}$ & $\begin{array}{l}\text { Taş, } \\
\text { Bilye }\end{array}$ & $\begin{array}{c}\text { Müzik } \\
\text { sesi }\end{array}$ & $\begin{array}{c}\text { Sincap, } \\
\text { inek, } \\
\text { uçak }\end{array}$ & $\begin{array}{l}\text { Teneke } \\
\text { içindeki } \\
\text { taşlar }\end{array}$ \\
\hline Ç 4 & $\mathrm{E}$ & Araba & Motor & $\begin{array}{l}\text { Biçer } \\
\text { Döver }\end{array}$ & Robot & Misket & Misket & Araba & $\begin{array}{l}\text { Misket } \\
\text { dönüyo }\end{array}$ \\
\hline Ç 5 & K & Yılan & Araba & Dinozor & Ambulans & - & Müzik sesi & Araba & Kuş \\
\hline Ç 6 & $\mathrm{~K}$ & Yllan & Çeşme & Ördek & Robot & Lego & Saz sesi & Araba & Misket \\
\hline Ç 7 & $\mathrm{E}$ & Kedi & Araba & - & $\begin{array}{c}\text { Ateş } \\
\text { atan } \\
\text { polis } \\
\text { arabası }\end{array}$ & - & Şark1 & $\begin{array}{c}\text { Gülüyor } \\
\text { Motor } \\
\text { Ateș }\end{array}$ & Eğlencel \\
\hline Ç 8 & $\mathrm{~K}$ & Araba & $\begin{array}{c}\text { Oyuncak } \\
\text { bebek }\end{array}$ & - & $\begin{array}{l}\text { Hızlı } \\
\text { bir șey }\end{array}$ & Eşek & Davul & Ses-Müzik & $\begin{array}{c}\text { Zil } \\
\text { dönüyo1 }\end{array}$ \\
\hline Ç 9 & K & Araba & Araba & Bisiklet & Polis & Zincir & Müzik & $\begin{array}{c}\text { Şark1 } \\
\text { söyleyen } \\
\text { çocuk }\end{array}$ & - \\
\hline Ç 10 & $\mathrm{~K}$ & - & Araba & Kedi & $\begin{array}{c}\text { Civciv. } \\
\text { Telefon. } \\
\text { Araba }\end{array}$ & $\begin{array}{c}\text { Yürüyen } \\
\text { Ay1 }\end{array}$ & Piyano & Araba & $\begin{array}{c}\text { Lego } \\
\text { devrilme } \\
\text { sesi }\end{array}$ \\
\hline Ç 11 & $\mathrm{~K}$ & Yllan & Motor & Araba & \begin{tabular}{|c} 
Polis \\
Arabas1
\end{tabular} & Robot & Eğlenceli & Araba & $\begin{array}{c}\text { Top } \\
\text { dönüyor }\end{array}$ \\
\hline
\end{tabular}

Tablo 3 (Devamı). Dinletilen Seslerin Neye Benzediğine Dair Verilen Cevaplar

Üçüncü soruda ise dinletilen bu seslerin çocuklardaki çağrışımlarını ölçmek adına seslerin onlara etkisi sorulmuş, yanıt vermekte zorluk çeken öğrencilere ise belirli sıfatlar söylenerek, içlerinden o sesle ilgili olduğunu düşündüğü kavramı seçmesi istenmiştir. Çalışmanın ikinci aşamasında ise sesleri dinletmeden sadece ürünleri göstererek çocuklardan oyuncakların formlarına dair yorum yapmaları istenmiştir. Burada karşılıkı değerlendirmenin daha rahat yapılacağı düşünülerek birinci oyuncaktan başlamak suretiyle her bir oyuncağa ait ses ve görsele yapılan yorumlar Tablo 4'de bir arada gösterilmiştir.

Birinci oyuncakla ilgili elde edilen bulgulardan da anlaşılacağı üzere ürün görseline yapılan değerlendirmelerin daha kararlı olması, görselin çocukların bir ürünü yorumlamasında daha etkili olduğunu göstermektedir. Ses ve formun uyuşması noktasında bir değerlendirme yapılacak olursa sese yapılan "ince" yorumuyla, ürüne yapılan "ince" yorumundaki sayısal fazlalıkta olduğu gibi kısmen de olsa tutarlı gözükmektedir. 


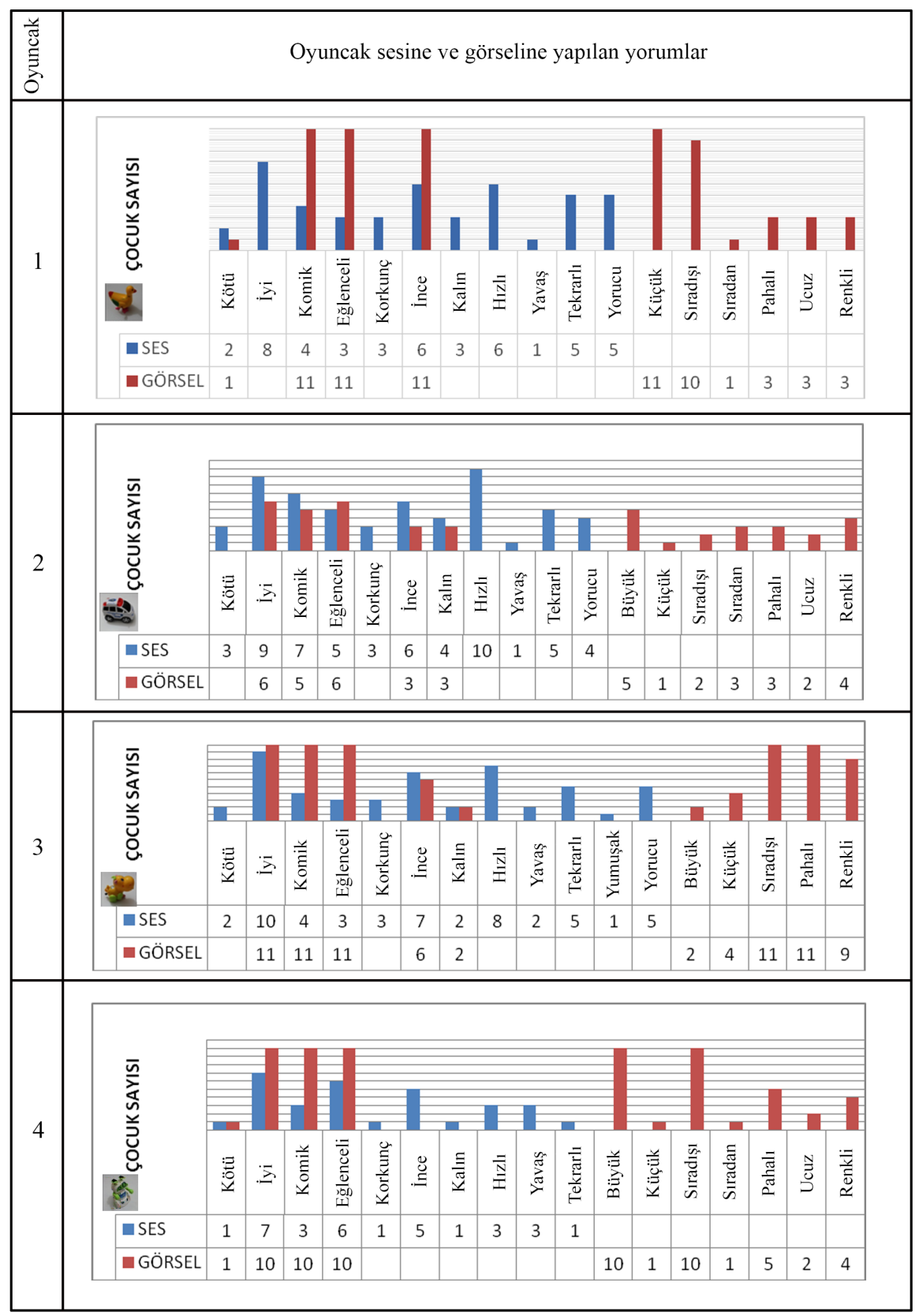

Tablo 4. Çocukların, Oyuncak Ses ve Görselleri ile İlgili Yaptıkları Değerlendirmeler 


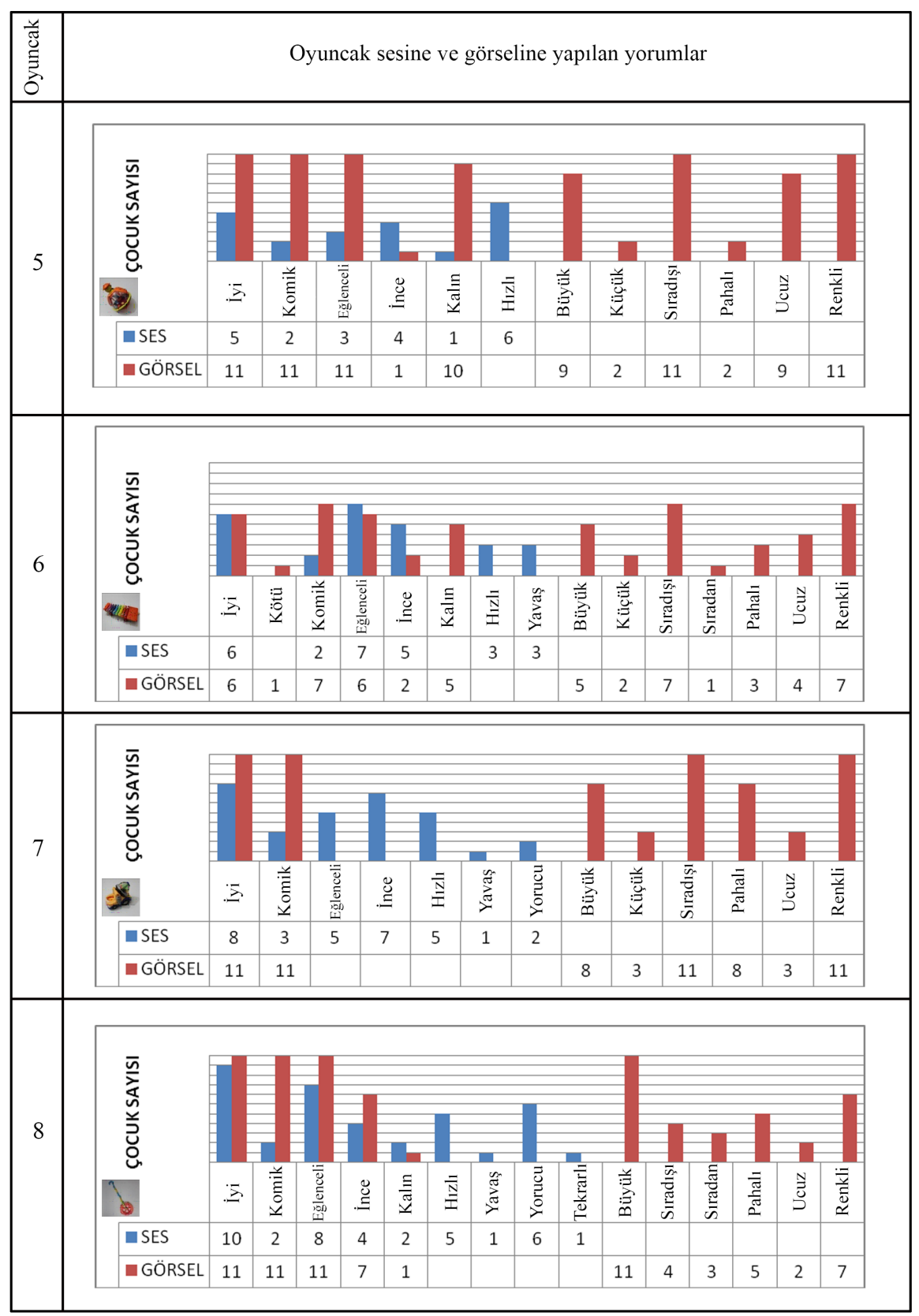

Tablo 4 (Devamı). Çocukların, Oyuncak Ses ve Görselleri ile Illgili Yaptıkları Değerlendirmeler 
İkinci oyuncağın sesiyle ilgili yapılan değerlendirmelerde ses hareketli ve hızlı bulunduğu halde formun değerlendirmesinde aynı veya benzer yorumların yapılmadığı görülmüştür. Üçüncü oyuncağın formuna dair değişik, eğlenceli, komik gibi değerlendirmeler yapılmış olup, ses ve görsel genel olarak güzel bulunsa da sesinin sadece 4 kişi tarafından komik, 3 kişi tarafından eğlenceli, 5 kişi tarafından da yorucu bulunması, bu örnekte ürün formu ve çıkardığı seste bir uyumsuzluk olduğunun göstergesidir. Dördüncü oyuncak olan robotta da benzer bir durumla karşılaşılmıştır. Oyuncağın formuna dair yapılan değerlendirmelerde ürün tüm öğrenciler tarafından güzel, değişik, eğlenceli, değerli ve komik bulunmuştur. Fakatses değerlendirmesine bakıldığında sadece 3 kişinin ürünün çıkardığı sesi komik, 6 kişinin eğlenceli, 7 kişinin de güzel bulması form-ses uyumsuzluğunu bu örnekte de göstermektedir. Beşinci oyuncak form olarak tüm öğrenciler tarafından güzel, değişik, eğlenceli, renkli ve komik bulunsa da çıkardığı sese yapılan yorumlarda durumun o kadar pozitif olmadığı gözükmektedir. Sadece 3 kişinin eğlenceli ve 2 kişinin komik bulduğu sesin, bu ürünle örtüşmediği yorumu yanlış olmayacaktır. Altıncı oyuncak olan ve müzik aletine benzeyen üründeki değerlendirmelerde bundan önceki ürünlerde olduğu kadar büyük bir farkın olmadığı görülmektedir. Anımsadıkları bir sese sahip olması ve bunun da ürünün formuyla birleşmesi sonucu tutarlı bir değerlendirme yapıldığı söylenebilir. Dozer mantığıyla tasarlanmış olan yedinci oyuncak ile ilgili yapılan değerlendirmelere bakılacak olursa, bu ürünün de ses ve görseline farklı yorumların yapıldığı görülmüştür. Ürünün formuna dair yapılan değerlendirmelerde tüm öğrenciler ürünü güzel, değişik, renkli ve komik bulurken, ürünün çıkardığı ses aksine 2 kişi tarafından yorucu ve sadece 5 kişi tarafından eğlenceli bulunmuştur. Sekizinci ve son oyuncak ise sesli yürüteç tarzında bir oyuncak olup tüm çocuklar tarafından güzel, büyük, eğlenceli ve komik bulunmuştur. Çıkardığı ses ile ilgili yapılan yorumlara bakıldığında oyuncak sesi 8 kişi tarafından eğlenceli bulunsa da 6 kişi tarafından da yorucu bulunmuştur. Yine de çıkan zil sesinin çocuklar tarafından güzel bulunması, oyun esnasında çok da fazla rahatsız olmayacaklarını göstermektedir.

Çalışmanın üçüncü ve son aşaması olan ses-ürün eşleştirme aşamasında ise ortaya çıkan sonuçlar Tablo 5'de aktarılmıştır. Bu aşamada oyuncaklar çocukların önündeyken, temas etmeden sesler tekrar sırayla dinletilerek, çocuklardan duydukları sesleri ürünlerle eşleştirmeleri istenmiştir. Bu değerlendirme sonuçlarına göre 2, 5, 7 ve 8 numaralı oyuncaklarda büyük oranda eşleştirme yapıldığı görülmektedir. Ses ve görsele yapılan yorum karşılaştırmalarına bakılacak olursa sesin ayrı dinletilip formun ayrı gösterilmesi sonucu oyuncakların ses ve görseline yapılan yorumların pek örtüşmediği görülmüştür. Fakat çocuklar karşılarında ürünü görerek 
sesin de eş zamanlı olarak dinletilmesiyle, üründeki bazı bileşenlerden yola çıkarak yaptıkları çıkarımlarla doğru eşleştirmeyi yapabilmişlerdir. Bu noktadan yola çıkarak duyuların harekete geçirilmesi noktasında sesin, görsel algının önemli bir destekçisi olduğu söylenebilir.

\begin{tabular}{|c|c|c|c|c|c|c|c|c|c|}
\hline Çocuk & $\begin{array}{l}\text { Kiz/ } \\
\text { Erkek }\end{array}$ & Ses 1 & $\begin{array}{l}\text { Ses } 2 \\
0\end{array}$ & $\frac{5}{\operatorname{Ses} 3}$ & $\begin{array}{l}8 \\
\text { Ses } 4\end{array}$ & $\begin{array}{l}\text { Ses } 5 \\
\text { S. }\end{array}$ & $\begin{array}{l}\text { Ses } 6 \\
\text { Ses }\end{array}$ & $\begin{array}{l}6 \\
\operatorname{Ses} 7\end{array}$ & $\begin{array}{r}28 \\
\text { Ses } 8\end{array}$ \\
\hline Ç 1 & K & O_4 & O_ 8 & O_4 & O_2 & O_7 & O_ 8 & O_3 & - \\
\hline Ç 2 & $\mathrm{E}$ & $\mathrm{O}_{-} 1$ & O_2 & O_3 & $\begin{array}{l}\mathrm{O}_{-} 4 \\
\mathrm{O} \_2\end{array}$ & $\mathrm{O}_{5} 5$ & O_6 & O_7 & O_8 \\
\hline Ç 3 & K & O_2 & O_4 & O_1 & O_2 & O_5 & $\begin{array}{l}\mathrm{O}_{-} 5 \\
\mathrm{O}_{-} 6\end{array}$ & O_7 & O_8 \\
\hline Ç 4 & E & O_1 & O_2 & $\begin{array}{l}\mathrm{O}_{-3} 3 \\
\mathrm{O} / \mathrm{1}\end{array}$ & O_4 & $\begin{array}{l}\mathrm{O}_{-} 5 \\
\mathrm{O}_{-} 7\end{array}$ & - & O_7 & $\begin{array}{l}\mathrm{O}_{-} 8 \\
\mathrm{O}_{-} 5\end{array}$ \\
\hline Ç 5 & K & O_7 & O_2 & O_4 & O_2 & O_5 & O_7 & $\mathrm{O}_{-} 7$ & O_8 \\
\hline Ç 6 & K & O_3 & O_7 & O_5 & O_4 & O_6 & O_6 & $\begin{array}{c}\mathrm{O}_{-} 5 \\
\mathrm{O}_{-} 7\end{array}$ & O_8 \\
\hline Ç 7 & E & O_1 & O_2 & O_3 & O_4 & O_5 & O_7 & $\begin{array}{l}\mathrm{O}_{-} 7 \\
\mathrm{O}_{-} 8\end{array}$ & O_8 \\
\hline Ç 8 & K & $\mathrm{O}_{-} 7$ & O_3 & $\mathrm{O}_{-} 3$ & O_2 & O_5 & O_6 & $\mathrm{O}_{-7} 7$ & O_8 \\
\hline Ç 9 & K & O_4 & O_2 & O_1 & O_4 & O_5 & $\begin{array}{l}\mathrm{O}_{-} 5 \\
\mathrm{O}_{-} 7\end{array}$ & O_2 & O_6 \\
\hline Ç 10 & K & O_1 & O_2 & $\begin{array}{l}\mathrm{O}_{-} 3 \\
\mathrm{O}_{-} 4\end{array}$ & $\begin{array}{c}\mathrm{O}_{7} 3 \\
\mathrm{O}_{-} 6\end{array}$ & - & - & - & - \\
\hline Ç 11 & K & O_4 & O_2 & - & O_3 & - & O_6 & O_4 & O_8 \\
\hline \multicolumn{2}{|c|}{$\begin{array}{l}\text { Doğru Eşleş̧irme } \\
\text { (Toplam) }\end{array}$} & 4 & 7 & 5 & 5 & 7 & 5 & 7 & 8 \\
\hline
\end{tabular}

Tablo 5. Ses-Oyuncak Eşleştirmesi Sonuçları 


\section{Sonuç ve Öneriler}

Bu araştırma kapsamında kullanıcı-çevre etkileşiminden kullanıcı-ürün etkileşimine kadar olan boyutta görsel ve duysal uyarıların bu etkileşime katkısı sorgulanırken, algıyı oluşturan faktörler çok boyutlu olarak incelenmiştir. Ürün seslerinin, ürün görsellerini anlamlandırmamızda ve algılamamızdaki öneminden yola çıkarak bunun çocuklar üzerindeki etkisini sorgulamak amacıyla ilköğretim çağındaki çocuklarla oyuncak üzerinden yapılan çalışmada, ses-görsel etkileşimi üzerine önemli sonuçlar elde edilmiştir. Ürünlerdeki dolaylı veya istemli seslerin tasarımları rastlantıya bırakılmaması gerekmekte olup, ürünün tercih edilirliğinden, yaşam süresinin uzun olup olamayacağına, çocuk üzerindeki psikolojik etkisine kadar birçok faktörü belirleyici unsur olması açısından önemlidir. Bu yüzden ürün geliştirme aşamasında kullanıcı ihtiyaçlarını iyi analiz etmek, onların duyularına hitap eden ürünler geliştirmek, tüm ses ve ürün tasarımcılarının sorumluluğu dâhilinde olmalıdır. Bu araştırma Ankara ilinde belirlenen bir ilköğretim okulunda yapılmıştır ve nitel araştırmaların bir sınırlılığı olarak genellenememektedir. Bu nedenle araştırmanın bulguları doğrultusunda yapılacak diğer araştırmalarda daha geniş örneklem ile farklı okullarda nicel ve nitel verilerin birlikte kullanıldığı araştırmaların uygulanması önerilmektedir. 


\section{Kaynakça}

Akbulut, D. (2009). "Günümüzde Geleneksel Oyuncaklar”, Millî Folklor Dergisi, Yıl 2I, Sayı 84.

Aydınlı, S. (1992). Mimarlıkta Görsel Analiz. İstanbul: iTÜ Mim. Fak. Baskı Atölyesi.

Bayazıt, N. (20I I). Endüstri Tasarımı Temel Kavramları, İstanbul: İdeal Kültür Yayıncılık A.Ş.

Blakemore, J. E. O. ve Centers, R. E. (2005). “Characteristics of boys' and girls' toys”, Sex Roles, 53, 619-633.

Csikszentmihalyi, M. ve Robinson, R. E. (1990). The Art of Seeing: An Interpretation of the Aesthetic Encounter. Los Angeles: Getty Publications.

Çağlayan, S., Korkmaz, M. ve Öktem G. (20/4). “Sanatta Görsel Algının Literatür Açısından Değerlendirilmesi”, Eğitim ve Öğretim Araştırmaları Dergisi, Cilt:3, Sayı: I, I60-I 73.

Çelebi, D. B. (2007). Türkiye ve Azerbaycan'daki çocuk oyunları ve oyuncaklarının karşılaştırmalı olarak incelenmesi, Yayınlanmamış Yüksek Lisans Tezi, Muğla Üniversitesi Sosyal Bilimler Enstitüsü, Muğla.

Desmet, P. M. A. ve Hekkert, P. (2007). “Framework of product experience”, International Journal of Design, I(I), 57-66.

Dökmen, Ü. (1994). Okuma Becerisi, İlgisi ve Alışkanlı̆̆ Üzerine Psiko-Sosyal Bir Araştırma. Ankara: MEB Yayınları.

Erhan, i. (1978). Endüstri Tasarımında Görsel Bildirişim, Doktora Tezi, İstanbul Devlet Güzel Sanatlar Enstitüsü, İstanbul.

Genç, A. ve Sipahioğlu, A. (1990). Görsel Algılama- Sanatta Yaratıcı Süreç. İzmir: Sergi Yayınları.

Hekkert, P. (2006). "Design aesthetics: Principles of pleasure in product design”, Psychology Science, 48(2), I57-I72.

Hekkert, P. ve Leder, H. (2008). “Product aesthetics”. In H. N. J. Schifferstein\& P. Hekkert (Eds.), San Diego. CA: Elsevier. Product Experience. 259-286.

Jackson, K. M. (200I). "From control to adaptation: America's toy story”, Journal of American and Comparative Cultures, I (2), I39- 145.

Kim, M. (2002). "Parents' perceptions and behaviors regarding toys for young children's play in Korea”, Education, 122 (4), 793-807. 
McCormick, E. J. (1970). Human Factors Engineering. New York: McGraw-Hill, Inc.

Özcan, Z., Bayraktar, N., Göker, N. ve Tekel, A. (2003). “Kente Dair Analitik Bir Çözümleme: Sokaklar ‘ilk Yıl Şehir Planlama Atölyesi Deneyimi”, Gazi Üniversitesi Müh. Mim. Fak. Dergisi, Cilt 18, No 2, I7-30.

Özcan, E. ve Van Egmond, R. (20/2). "Basic Semantics of Product Sounds”, International Journal of Design, 6(2), 4I-54.

Schafer, C. (2006). Ömür Törpüsü mü? Bal Küpü mü? (Çev: C. Aydın), İstanbul: Sistem Yayıncilık.

Van Egmond, R. (2008). "The Experience of Product Sounds". In H. N. J. Schifferstein, \& P. Hekkert (Eds.), Amsterdam: Elsevier Product Experience, 69-89.

Wilbrandt, E. (2009). Maria Montessori Yöntemiyle Çocuk Eğitim Sanatı. İstanbul: Sistem Yayıncilık.

Yalçınkaya, T. (1993). “0-6 Yaş Arasında Oyun ve Oyuncaklar”, M.Ü Atatürk Eğitim Fakültesi Eğitim Bilimleri Dergisi, Sayı:5, I69-I 74.

Yıldırım, A. ve Şimşek, H. (2008). Sosyal Bilimlerde Nitel Araştırma Yöntemleri. Ankara: Seçkin Yayınları.

\section{Görsel Kaynaklar}

Desmet, P. (2003). “A Multilayered Model of Product Emotions”, The Design Journal, 6:2, s. $4-13$

Langeveld, L., Van Egmond, R., Jansen, R., Özcan, E. (20/3). "Product Sound Design: Intentional and Consequential Sounds", Advances in Industrial Design Engineering, Prof. Denis Coelho (Ed.), InTech, DOI: 10.5772/55274.

Özcan, E., Van Egmond, R. (2008). “Product Sound Design: An Inter-Disciplinary Approach”, Design Research Society Biennial Conference (DRS2008), Sheffield, UK.

\section{Internet Kaynakları}

Internet: AÖF, (20I4). Okul Öncesi Eğitimde Araç Gereç Geliştirme, Ünite 5, Eğitici

Oyuncak Yapma-I. Web:http://www.ataturkuni.com/ow_userfiles/plugins/forum/ attachment_1322_54419e92b87d8_54419e88d6920_ARA\%C3\%87-VE-GERE\%C3\%87GEL\%C4\%BO\%C5\%9ET\%C4\%BORME-5.pdf adresinden 14.01.20I5 tarihinde alınmıştır.

Internet: TDK, (20I5). Web:http://www.tdk.gov.tr/index.php?option=com_ gts\&arama = gts\&guid=TDK.GTS.54bab078709792. I I 922479 adresinden I 3.06.20/5 tarihinde alınmıştır. 